\title{
Bone dating at the Zagreb Radiocarbon Laboratory, Croatia
}

\author{
Andreja Sironić \\ Jadranka Barešić \\ Ines Krajcar Bronić
}

https://doi.org/10.17234/METARH.2019.8

\author{
Andreja Sironić \\ Jadranka Barešić \\ Ines Krajcar Bronić \\ Ruđer Bošković Institute \\ Bijenička cesta 54 \\ HR - 10000 Zagreb \\ asironic@irb.hr \\ jbaresic@irb.hr \\ krajcar@irb.hr
}

Bone remains can contain information of date of death, disease, nutrition habits and diet, location/movement, genealogy etc. of an individual and therefore bones represent a very interesting material for archaeological studies. Bones are composed of soft organic (collagen) and a mineral (bioapatite) tissue. Both tissues can be used for radiocarbon dating when certain conditions are satisfied. At the Zagreb Radiocarbon Laboratory, there are two techniques for radiocarbon dating: by liquid scintillation counting (LSC) and by accelerator mass spectrometry (AMS). The AMS technique enables dating of collagen from quite small bone fragments and also dating of bone apatite from cremated bones. Here we present our results of bone radiocarbon dating within the international radiocarbon intercomparison exercises and two case studies of ${ }^{14} \mathrm{C}$-AMS bone dating from two archaeological sites in Croatia: the Sokol fortress from Konavle and the St. Stephen church in Pustijerna, Dubrovnik.

Keywords: radiocarbon dating, AMS, bones, cremated bones, collagen, apatite, radiocarbon intercomparison

\section{Introduction}

Bone can contain information about histology, paleobiology and paleoecology of fossil vertebrates, diet, date, contemporaneous climate, body temperature, provenance, mobility, conditions after the death (diagenesis), etc., obtained by analyzing its morphology, diagenesis rate, rare earth elements composition, stable and radioactive isotopes (Tütken and Vennemann 2011).
${ }^{14} \mathrm{C}$ radioactive decay used for dating (Arnold and Libby 1949; Libby et al. 1949; Libby 1955) revolutionized archaeology and paleontology. In archaeology, wood and bone remains are materials mostly used for dating. However, unlike wood, bones are much more prone to contamination with exogenous carbon. This feature has to be overcome by a series of cleaning and extraction steps. 
In the Laboratory for low-level radioactivities of the Ruđer Bošković Institute (also known as the Zagreb Radiocarbon Laboratory) bone dating has been conducted since the early 1970s (Srdoč et al. 1973; Horvatinčić et al. 1983) by the gas proportional counting technique (GPC). Liquid scintillation counting (LSC) technique was implemented in 2004, with two sample preparation techniques: $\mathrm{CO}_{2}$ absorption or benzene synthesis (Horvatinčić et al. 2004; Krajcar Bronić et al. 2009). Sample preparation for accelerator mass spectrometry (AMS) was established in 2007 (Krajcar Bronić et al. 2010; Sironić et al. 2013). It enabled dating of milligram size samples, thus fairly broadening the application of the ${ }^{14} \mathrm{C}$ method. By this point, only the collagen extracted from bones was applied in ${ }^{14} \mathrm{C}$ dating, while by introducing the AMS technique, apatite from cremated bones became eligible for dating.

Here we present the bone dating procedure at the Zagreb Radiocarbon Laboratory, focusing on the AMS technique. We also present two case studies of bone dating from two archaeological sites, St Stephen in Pustijerna, Dubrovnik and Sokol fortress in Konavle.

\section{${ }^{14} \mathrm{C}$ bone dating principle and problems associated}

${ }^{14} \mathrm{C}$ is produced from the interaction of nitrogen with cosmic rays in the upper atmosphere, forms $\mathrm{CO}_{2}$ molecule and enters the biosphere through photosynthesis, primary and secondary consumers. In this way, the ${ }^{14} \mathrm{C}$ activity of the terrestrial biosphere generally reflects the ${ }^{14} \mathrm{C}$ activity of the atmosphere, while aquatic biospheres (marine and freshwater) reflect their own initial carbon source, which will be discussed later within reservoir effect. After the death of an organism, ${ }^{14} \mathrm{C}$ is no longer replenished, and its activity decreases in accordance with the ${ }^{14} \mathrm{C}$ radioactive decay. By measuring the remaining ${ }^{14} \mathrm{C}$ activity in the organism's remains, the time passed from death to the moment of measurement can be calculated. The ${ }^{14} \mathrm{C}$ half-life of 5730 years makes the method suitable for dating of up to 60,000 years old materials. Since the concentration of ${ }^{14} \mathrm{C}$ in atmospheric $\mathrm{CO}_{2}$ is very low, only $10^{-10} \%$, special techniques needed to be developed in order to isolate carbon from the analysed material and prepare it in a form of matrix suitable for physical measurement (gas $\mathrm{CH}_{4}$, benzene, graphite, Srdoč et al. 1971; Horvatinčić et al. 2004; Sironić et al. 2013). Therefore the radiocarbon method is destructive for the material.

In nature, stable ${ }^{12} \mathrm{C}(98.9 \%)$ and ${ }^{13} \mathrm{C}(1.1 \%)$ carbon isotopes also exist. The ratio of ${ }^{13} \mathrm{C} /{ }^{12} \mathrm{C}$ varies for different materials. During chemical or physical reactions of the transformation of one material (compound) to an other, isotope fractionation occurs, meaning that the ${ }^{13} \mathrm{C}$ and ${ }^{12} \mathrm{C}$ composition in the product is different than that in the source material. Composition of ${ }^{13} \mathrm{C}$ is expressed as a $\delta^{13} \mathrm{C}$ value, which is the relative deviation of a ${ }^{13} \mathrm{C} /{ }^{12} \mathrm{C}$ ratio in a material compared to that in a standard (PDB, Pee Dee Belemnite; Mook 2000). Values of $\delta^{13} \mathrm{C}$ can be used for controlling the purity of the samples, or for gaining information of the samples' origin.

Bone consists of mineral (apatite) and organic components (collagen). Collagen ( 23 wt\%, Wopenka and Pasteris 2005; Glimcher 2006) is built of long protein fibers, with a molecular weight 300,000 (i.e. $300 \mathrm{kDa}$ ), mostly composed of amino-acids as glycine (Gly), proline (Pro) and hydroxyproline (Hyp), Hyp being typical for collagen. Collagen fibers are inter grown by $\mathrm{nm}$-size bioapatite crystals of a general chemical formula $\mathrm{Ca}_{10}\left(\mathrm{PO}_{4}\right)_{6} \mathrm{OH}_{2^{\prime}}$ constructing the hard tissue. The phosphate in apatite is substituted by carbonate ions $0.5-1 \mathrm{wt} \%$. Both components contain carbon from the atmosphere making them both potentially suitable for ${ }^{14} \mathrm{C}$ dating. The same structure can be found in antler, bony part of horn and tooth dentine or ivory. Enamel part of a tooth is similar, with the exception that organic content is up to $1 \mathrm{wt} \%$ and the bioapatite crystals are the order of magnitude larger and with negligible porosity which makes enamel bioapatite not prone to diagenetic alteration.

\section{Radiocarbon dating of collagen}

The first attempts to date bones considered using the carbon from apatite (e.g. Haynes 1968) or collagen (Berger et al. 1964). However, due to bone diagenesis (adsorption of ions, diffusion, ion exchange in the apatite lattice or precipitation of secondary minerals in pore spaces) carbon from apatite can also contain exogenous carbon. The very high porosity of the bone apatite makes the environmental carbonate difficult to be selectively removed, so the extraction of collagen was developed by gelatinization of collagen (Longin 1971). After mechanical cleaning, bone is decalcified by treatment in acid followed by gelatinization step. Bone remains can be treated with the base before gelatinization to remove humic substances (e.g. DeNiro and Epstein 1981). Further on, ultrafiltration can be applied after the gelatinization step. In general, laboratories use ultrafilters that concentrate molecules larger than $30 \mathrm{kDa}$, which are likely to be long protein chains of collagen so that the smaller organic molecules that could be part of contaminants from the 
soil are removed (e.g. Brown et al. 1988; Bronk Ramsey et al. 2004; Higham et al. 2006). However, it is important that the ultrafilters go through a pre-cleaning step since they can be a source of contamination (Hüls et al. 2007). Amino-acid extraction could be used to further eliminate contaminants (Yuan et al. 2000). During bone diagenesis a substantial part of collagen could be lost, making it not suitable for dating, so pre-screening techniques, such as percent of nitrogen $(\% \mathrm{~N})$ in whole bone powder, should be considered (Brock et al. 2010a) for the bones with $<1 \%$ of collagen yield. In general, bones with $\mathrm{C} / \mathrm{N}$ ratio between $2.9-3.5$ (van Klinken 1999) and with collagen yield higher than $1 \mathrm{wt} \%$ can be pre-cleaned using the Longin method with base step pre-cleaning. For poorly preserved bones, with low collagen yield or elevated $\mathrm{C} / \mathrm{N}$ ratio, the extraction of the Hyp amino acid can be used. Marom et al. (2013) showed that, in poorly preserved bones, collagen could be contaminated with exogenous organic molecules chemically bonded to amino acids, in which case selectively extracted Hyp molecules could be used for dating.

For collagen, $\delta^{13} \mathrm{C}$ values vary regarding the diet of an animal/human. Collagen $\delta^{13} \mathrm{C}$ value increases with the degree of a trophy (Schoeninger et al. 1983) meaning that herbivore bones collagen has lower $\delta^{13} \mathrm{C}$ values than omnivore or carnivore collagen. $\delta^{13} \mathrm{C}$ value is also different for plants: $\mathrm{C}_{3}$ photosynthetic cycle plants (most plants) have $\delta^{13} \mathrm{C}$ value around $-27 \%$, while $\mathrm{C}_{4}$ photosynthetic cycle plants (e.g. maize, sugar beet, millet) have it around -12\%o (Waller and Mewis 1979; Hoefs 1997). This also has an influence on the net $\delta^{13} \mathrm{C}$ value of collagen. For example, herbivore feeding on $\mathrm{C}_{3}$ plants would have $\delta^{13} \mathrm{C}$ value around -26\% (compensation due to the higher trophy level from plants to animal), while those feeding on $\mathrm{C}_{4}$ around $-11 \%$. If the diet is mixed $\delta^{13} \mathrm{C}$ value would lie in-between (Fischer et al. 2007; Lamb et al. 2012; Salazar-Garcia et al. 2014).

Marine diet can have a strong impact on ${ }^{14} \mathrm{C}$ dating, due to the marine reservoir effect. Surface marine waters contain carbon depleted of ${ }^{14} \mathrm{C}$ resulting in higher apparent age of marine biota ( 400 years, Hughen et al. 2004). Marine biota also has higher $\delta^{13} \mathrm{C}$ values comparing to terrestrial animals. Terrestrial animals (including humans) consuming marine biota can have $\delta^{13} \mathrm{C}$ of collagen as high as $-16 \%$ (Johansen et al. 1986; Ascough et al. 2007,2012 ). In order to compensate for the marine reservoir effect when radiocarbon dating, paleo/archaeodiet can be determined by combining $\delta^{13} \mathrm{C}$ with $\delta^{15} \mathrm{~N}$ and $\delta^{34} \mathrm{~S}$ values, and radiocarbon date can be corrected accordingly (Lightfoot et al. 2014; Sayle et al. 2014; Dury et al. 2018).

\section{Radiocarbon dating - bioapatite}

When there is enough collagen to perform dating, bioapatite is usually not considered. Structural carbonate in bioapatite originates from blood bicarbonate and is in close relationship with the food intake of the human/ animal. Skeletal remains from humid climate regions, such as Europe or America, show a large difference between ${ }^{14} \mathrm{C}$ dates of bioapatite and collagen, due to bone diagenesis. However, calcined bones (should not be confused here with cremated calcinated bone, which are discussed later) from arid regions like Africa or Arabia can be reliably ${ }^{14} \mathrm{C}$ dated from a bioapatite carbonate (Zazzo and Saliège 2011).

Bioapatite can also be used for dating in case of cremated bones, i.e., bone remains that underwent burning on temperatures higher than $600^{\circ} \mathrm{C}$. The high temperature transforms highly porous crystal lattice of bioapatite to much denser lattice with higher crystallinity, making it resistible to diagenesis and suitable for radiocarbon dating (Lanting et al. 2001; van Strydonck et al. 2005; Naysmith et al. 2007; Hüls et al. 2010). It was believed that the structural carbonate survives such high temperatures, while all collagen carbon is lost. However, later studies showed that cremated bones exhibit the "old wood" effect (Olsen et al. 2013) and that the major part of structural carbonate in the cremated bones (can be up to $86 \%$ ) comes from fuel used for burning of the bones (Hüls et al. 2010). Nevertheless, in most cases, it could be expected that the difference between the ${ }^{14} \mathrm{C}$ activity of the wooden fuel and the cremated bones is probably minimal and dating should always be considered within the broader context of the findings.

Cremated bones are suitable for dating if the crystal lattice underwent a complete transformation to high crystallinity lattice, i.e., that the cremation temperature was high enough. If the lattice is not thick enough, exogenous carbon from the environment can enter crystal lattice resulting in higher carbon content (comparing to phosphorus), lower $\delta^{13} \mathrm{C}$ values and eventually younger radiocarbon dates (van Strydonck et al. 2009). A sample should be checked for its color (pure white are better than yellowish or charred), crystallinity (checked with infra-red spectra), carbon to phosphorus ratio (C/P should be lower than $\sim 0.12$ ), and $\delta^{13} \mathrm{C}$ value (lower than $-19 \%$ ) (Olsen et al. 2008). Generally, carbon percentage should be lower than $0.25 \mathrm{wt} \%$, however, Major et al. (2019) showed that carbon percentage up to $0.56 \mathrm{wt} \%$ also gives a satisfactory radiocarbon age. 
Marine diet, i.e., marine reservoir effect should not have a significant influence on the dating of cremated bones, if the most structural carbon comes from burning fuel (Hüls et al. 2010), however, further studies need to be undertaken in this direction (Olsen et al. 2008).

\section{Bone dating at the Zagreb Radiocarbon Laboratory}

During 50 years of existence of the Zagreb Radiocarbon Laboratory about 7000 samples have been processed by GPC, LSC and AMS techniques. About $3.5 \%$ are bone samples, and $40 \%$ of bones have been analyzed by AMS alone, introduced to the Laboratory about a decade ago. AMS enabled analyses of much smaller bone fragments and teeth and also of the cremated bones (about $10 \%$ of bones). Currently, at the Laboratory two radiocarbon techniques are available, the LSC and AMS. For the LSC technique, carbon from bone is extracted by the Longin method (Longin 1971), and carbon is converted to benzene through a series of chemical reactions (collagen $\mathrm{CO}_{2}-\mathrm{Li}_{2} \mathrm{C}_{2}-\mathrm{C}_{2} \mathrm{H}_{2}-\mathrm{C}_{6} \mathrm{H}_{6}$, benzene, Horvatinčić et al. 2004; Krajcar Bronić et al. 2009). The activity of ${ }^{14} \mathrm{C}$ is measured in benzene by radioactive decay in a liquid scintillation counter. For LSC 2-4 g of carbon is required (80 - $400 \mathrm{~g}$ of bones). The AMS technique of graphite synthesis requires $1.5 \mathrm{mg}$ of carbon (1-5 $\mathrm{g}$ of bones).

\section{Experimental procedures for AMS and data reporting}

For collagen extraction, bone samples (1-5 g) are mechanically cleaned, rinsed in ultrapure water (UPW) in the ultrasonic bath, then in acetone, then again in UPW. This step removes a smaller amount of grease. In case bones have been treated with resins, for restoration/preservation purposes, 'soxhlet' method is applied (Bruhn et al. 2001), which implies rinsing the sample in series of solvents with increasing polarity, from the most hydrophobic to water (tetrahydrofuran, chloroform, n-hexane, acetone, methanol, water). After these precleaning steps, bone is demineralized at the room temperature by $1 \mathrm{M} \mathrm{HCl}$ until the completely gelatinous/soft bone texture is reached. This step removes carbonates from bones and fulvic acids, organic molecules present in soil derived from biota decomposition. Next, the sample is treated by $0.25 \mathrm{M} \mathrm{NaOH}$ solution (the base step) in order to remove the humic acids, also molecules derived from the organic part of the soil, that are soluble in bases. This is followed by treatment again in acidic solution $(1 \mathrm{M} \mathrm{HCl})$ to remove atmospheric $\mathrm{CO}_{2}$ adsorbed in bases.
This part is known as the A-B-A procedure (acid-base-acid, Goh and Molloy 1972; Gupta and Polach 1985; Brock et al. 2010b; Sironić et al. 2013; Dunbar et al. 2016). However, if it is estimated that in the base wash would result in considerable sample loss and that the sample is not likely to be contaminated with humic acids, this step can be omitted. The gelatinous rest is treated in UPW acidified with $\mathrm{HCl}$ to $\mathrm{pH} 2-3$ and $80{ }^{\circ} \mathrm{C}$ for 12 hours, dissolving the collagen. The solution is hot-filtered, through a glass fibre filters, removing the insoluble parts (e.g. roots, sediment, wood fragments, etc.). The filtrate is freeze-dried resulting in sponge-like collagen. Collagen is loaded in quartz tubes, sealed in the vacuum with $\mathrm{CuO}$ and $\mathrm{Ag}$-wool and put in the oven at $850^{\circ} \mathrm{C}$ to oxidize collagen to $\mathrm{CO}_{2}$.

Cremated bones are treated according to Lanting et al. (2001) and Olsen et al. (2008). 1-5 g of bones is precleaned with UPW. The bone is grinded and treated with $1.5 \%$ of $\mathrm{NaClO}$ (48 hours) to remove the remaining organics in order to free the bone surface for the next step. The carbonates from the surface, possibly containing exogenous carbon, are dissolved by $1 \mathrm{M}$ acetic acid (24 hours). After rinsing and drying, the sample is finely crushed, placed in a vessel with phosphoric acid (85\%) in a separate vessel portion and evacuated. The beaker is tilted, so the acid is poured into the portion with the crushed bone and left over night for the reaction of apatite carbonate hydrolysis to $\mathrm{CO}_{2}$ to take place.

A portion of $\mathrm{CO}_{2}$ obtained by either collagen combustion or apatite hydrolysis is separated for $\delta^{13} \mathrm{C}$ analyses on Isotope Ratio Mass Spectrometer (IRMS), while another portion is turned to graphite by zinc reduction with iron catalyst, pressed in aluminum targets for ${ }^{14} \mathrm{C} /{ }^{13} \mathrm{C}$ analyses on accelerator mass spectrometer (AMS, Krajcar Bronić et al. 2010; Sironić et al. 2013). The $\mathrm{CO}_{2}$ gas and the graphite from the samples are produced at the Zagreb Radiocarbon Laboratory, while both IRMS and AMS analyses are done at the Center for Applied Isotope Studies (CAIS), the University of Georgia, Athens, USA, or at the Scottish University Research Centre, (SUERC) Glasgow, UK.

Conventional radiocarbon age of the sample is calculated from ${ }^{14} \mathrm{C} /{ }^{13} \mathrm{C}$ values normalized to $-25 \%$, using Libby's half-life (5568 years). It is expressed as years BP ("Before Present" with "present" being the calendar year 1950) (Mook and van der Plicht 1999). Since the activity of ${ }^{14} \mathrm{C}$ in the atmospheric $\mathrm{CO}_{2}$ is time-variable due to changes in cosmic/solar radiation, the Earth magnetic field, climate, etc., the calculated ages have to be corrected, i.e., calibrated. The radiocarbon calibration curves are con- 


\begin{tabular}{|c|c|c|c|c|c|c|}
\hline Sample name & Age (known) & $\begin{array}{c}\text { Consensus age } \\
\text { age }_{\text {cncs }} \text { (BP) }\end{array}$ & $\mathbf{z}$ & A & $\begin{array}{c}\text { Measured age } \\
\text { age }_{\text {lab }}(\mathrm{BP})\end{array}$ & u-value \\
\hline $\begin{array}{l}\text { VIRI Sample E - } \\
\text { mammoth }\end{array}$ & $\sim 30000 \mathrm{BP}$ & $38772 \pm 2532$ & 4013 & 269 & $36834 \pm 473$ & 0.75 \\
\hline $\begin{array}{l}\text { VIRI Sample F - } \\
\text { horse }\end{array}$ & $<5000 \mathrm{BP}$ & $2525 \pm 69$ & 4014 & 239 & $2510 \pm 25$ & 0.20 \\
\hline $\begin{array}{l}\text { VIRI Sample H - } \\
\text { whale }\end{array}$ & 10000 BP & $9510 \pm 158$ & 4015 & 247 & $9452 \pm 26$ & 0.36 \\
\hline $\begin{array}{c}\text { VIRI Sample I - } \\
\text { whale }\end{array}$ & 10000 BP & $8328 \pm 176$ & 4016 & 244 & $8298 \pm 27$ & 0.17 \\
\hline $\begin{array}{l}\text { SIRI Sample B - } \\
\text { marine mammal }\end{array}$ & $\begin{array}{l}\sim 40000 \mathrm{BP} \\
\text { Pleistocene }\end{array}$ & $38727 \pm 284$ & 5284 & 767 & $38758 \pm 200$ & 0.09 \\
\hline $\begin{array}{l}\text { SIRI Sample C - } \\
\text { mammoth }\end{array}$ & $\begin{array}{c}{ }^{14} \mathrm{C} \text { background, } \\
\text { MIS } 7\end{array}$ & $0.00895^{*}$ & 5315 & 789 & $\begin{array}{c}0.00497^{*} \\
0.0012 \pm \\
0.0005^{1} \\
54025 \pm 3563^{2}\end{array}$ & \\
\hline
\end{tabular}

MIS 7 - Marine Isotope Stage (240-190 thousand years), *LOD-limit of detection expressed as fraction modern, ${ }^{1}$ fraction modern corrected for the laboratory background, ${ }^{2}$ age calculated from background corrected fraction.

TABLE 1. Bone samples from VIRI and SIRI exercises, their consensus ages and ages measured at the Zagreb Radiocarbon Laboratory. $Z$ is code for laboratory number, $\mathrm{A}$ is a code number of graphite, $\mathrm{u}$ is a statistical test u-score, defined in Eq1.

structed by measuring ${ }^{14} \mathrm{C}$ activity/conventional date in samples of known calendar dates (dendrochronologically dated tree rings, laminated sediment layers, speleothems dated by U-Th method, etc.). The calibration of conventional age results in the date range(s) of calendar years expressed as cal AD or cal BC (calibrated Anno Domini or calibrated Before Christ calendar years) with probability density function. The curve for calibration used in this report is IntCal13 (Reimer et al. 2013), and the computer program is OxCal v.4.3.2 (Bronk Ramsey 2017).

\section{International Radiocarbon Intercomparison exercises}

After the introduction of AMS to the Laboratory, there had been two international radiocarbon laboratory intercomparison exercises conducted: the Fifth International Radiocarbon Intercomparison (VIRI) and the Sixth International Radiocarbon Intercomparison (SIRI) exercises (Scott et al. 2007; 2010a; 2010b; 2017). Both exercises involved about 50 radiocarbon laboratories around the globe.

VIRI was a four-year project with three stages, comprised of grain, bone, wood, charcoal, shells and humic acids (total of 22 samples). SIRI was focused on natural samples, of wood, bone charcoal, barley mash and humic acids, a total of 12 samples. The results of dating the samples from VIRI and SIRI are published in Sironić et al. (2013) and Krajcar Bronić et al. (2015a). Here we compare the results of collagen bone dating from VIRI and SIRI in the Zagreb Radiocarbon Laboratory.

The description of samples, their consensus values and values measured at the Laboratory is presented in Table 1. A statistical test, u-score, defined as:

$\mathrm{u}=\mid$ age $_{\text {lab }}-$ age $_{\text {cncs }} \mid / \mathrm{V}\left(\sigma_{\text {lab }}^{2}+\sigma_{\text {cncs }}^{2}\right)$

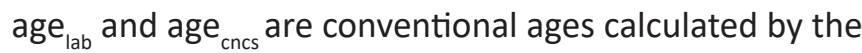
Laboratory and consensus intercomparison age, and $\sigma_{\text {lab }}$ and $\sigma_{\text {cncs }}$ are their uncertainties, respectively. If the u-score value is lower than 2 , the result is acceptable. Known age of the SIRI sample C-mammoth was $>60000$ $\mathrm{BP}$, making this sample material for testing the limit of detection (LOD) for the collagen radiocarbon measurement. For that reason, the resulted value is reported not as age, but as fraction modern, i.e., as the activity of ${ }^{14} \mathrm{C}$ measured in the sample expressed as a fraction of activity in a modern sample, modern sample activity is defined as $226 \mathrm{~Bq} / \mathrm{kgC}$.

All the calculated u-scores have the value below 1 , meaning that the values measured at the Laboratory for collagen bone samples are acceptable. The consensus LOD value for the background sample SIRI-C is actually about two times higher than the LOD values for the other background samples in SIRI (Scott et al. 2017) which means that in general radiocarbon laboratories have difficult 


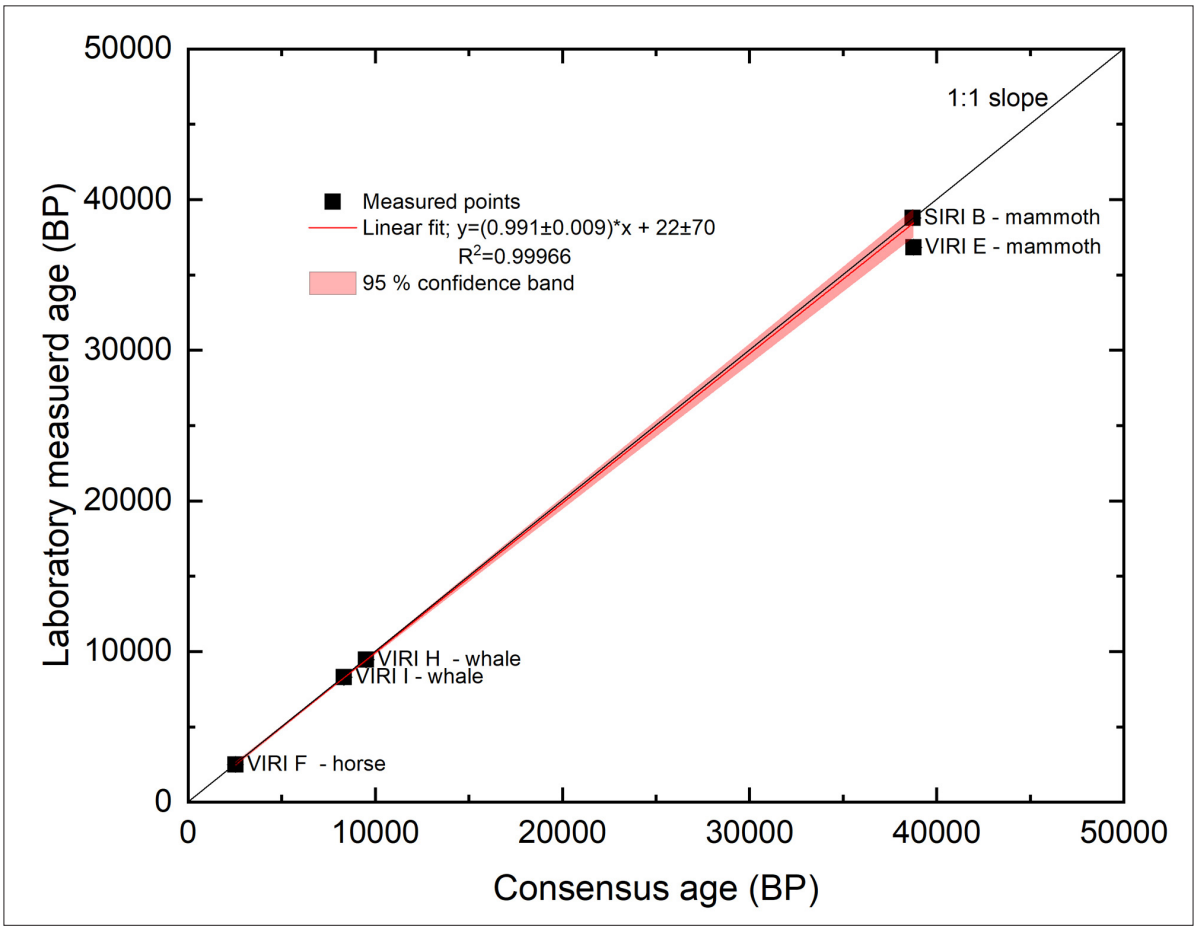

FIGURE 1. Correlation of Laboratory meas ured ages and the consensus ages for samples of bone collagen from VIRI and SIRI exercises.

times removing the contaminants from bones older than 55000 years. The Laboratory's LOD value is below the consensus value, although higher than LOD for standard background samples, yielding age of $54000 \pm 3600$ years. Therefore, the lowest age for bone collagen that can be reported by the Laboratory is about 50000 years.

The conventional ages for the bone samples measured at the Laboratory are correlated to the consensus ages from the VIRI and SIRI exercises in Figure 1. The correlation slope is close to $1(0.991 \pm 0.009)$ and $R^{2}=0.99966$, showing an excellent agreement between the two sets of data. The SIRI sample $\mathrm{C}$ is not shown since it should be below the detection limit.

\section{Cases of dating with AMS at the Zagreb Radiocarbon Laboratory}

Dating of bones from Sokol fortress

in Konavle near Dubrovnik

The Sokol fortress in Konavle was built on a huge rock formation and used as a control point in the Roman times and in the Justinian times. It was under several patrons in medieval times and under the Dubrovnik Republic until the Big Earthquake in AD 1667, after which it was abandoned in AD 1672.

In 2012 and 2013 an extensive archaeological excavation took place at the site. Among other investigations, skeletal remains of 27 individuals were examined anthropologically and radiocarbon dated (Krajcar Bronić et al. 2015b; Topić et al. In press). From the bones the collagen 


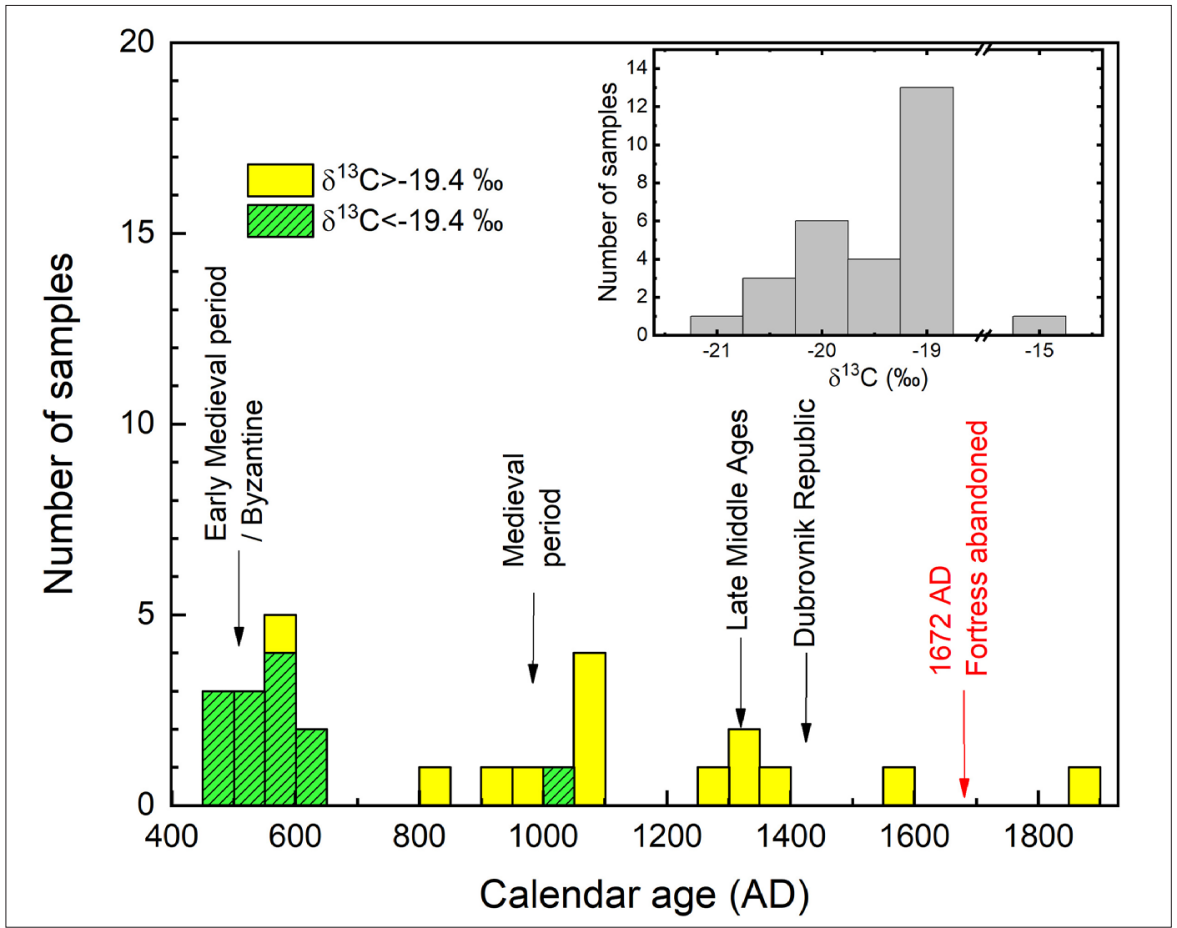

FIGURE 2. Frequency distribution of calendar ages for bones from the Sokol fortress, recalibrated by OxCal v.4.3.2 (Bronk Ramsey 2017). The number of samples for each date is presented as a number of samples with $\delta^{13} \mathrm{C}$ collagen higher and lower than $-19.4 \%$. The inner figure presents the frequency distribution of $\delta^{13} \mathrm{C}$ values for the same bone collagen samples.

was extracted, $\mathrm{CO}_{2}$ and graphite were prepared at the Zagreb Radiocarbon Laboratory and analyzed on IRMS and AMS at SUERC and CAIS. The collagen dates ranged from the $6^{\text {th }}$ to $16^{\text {th }}$ century, with one collagen dated to the $19^{\text {th }}$ century (Fig. 2). Majority of samples were dated to the $6^{\text {th }}$ century. The dated bone remains were of men, women and children, showing the continuation of settlement not only as a military character but also as a residential area around the fortress. $\delta^{13} \mathrm{C}$ values of the bones ranged from $-18.7 \%$ to $-20.8 \%$, typical for the bone human collagen omnivore of predominant $\mathrm{C}_{3}$ plant diet (Fig. 2, inner graph,). A shift from lower $\delta^{13} \mathrm{C}$ values $(<-19.4 \%)$ in the Byzantine times to higher values in later periods (>-19.4\%) implies a change in dietary habits of the Sokol fortress habitants.

\section{Dating of bones from St Stephen in Pustijerna church, Dubrovnik}

The St. Stephen in Pustijerna church is one of the most well-known and one of the 24 oldest churches in the historical core of the city of Dubrovnik (Peković 1998; 2010). The historical findings place it to a period between the $6^{\text {th }}$ century and the Big Earthquake in AD 1667 (Pekovic 1998; Regan and Nadilo 2006). During the archaeological excavations in 2011/2012, all cultural layers inside the church and church cemetery were included. Five human bone samples from the graveyard were radiocarbon dated (Krajcar Bronić et al. 2012; Topić et al. 2012). Samples were processed by collagen extraction and $\mathrm{CO}_{2}$ and graphite preparation for IRMS and AMS analyses at CAIS. In Figure 3 and Table 2 the re-calibrated (by OxCal v.4.3.2) radiocarbon ages of the bone collagen samples are presented. $\delta^{13} \mathrm{C}$ values range from $-20 \%$ to $-18 \%$ which could be attributed to the mixed diet, similar as the findings for the Sokol fortress Medieval period. The oldest bone (Z-4787) was dated to cal AD 778-880 (median cal AD 832), while the youngest (Z-4792) to cal AD $1262-1285$ (median cal AD 1273) showing the continuous use of the graveyard from $8^{\text {th }}$ to $13^{\text {th }}$ century. 


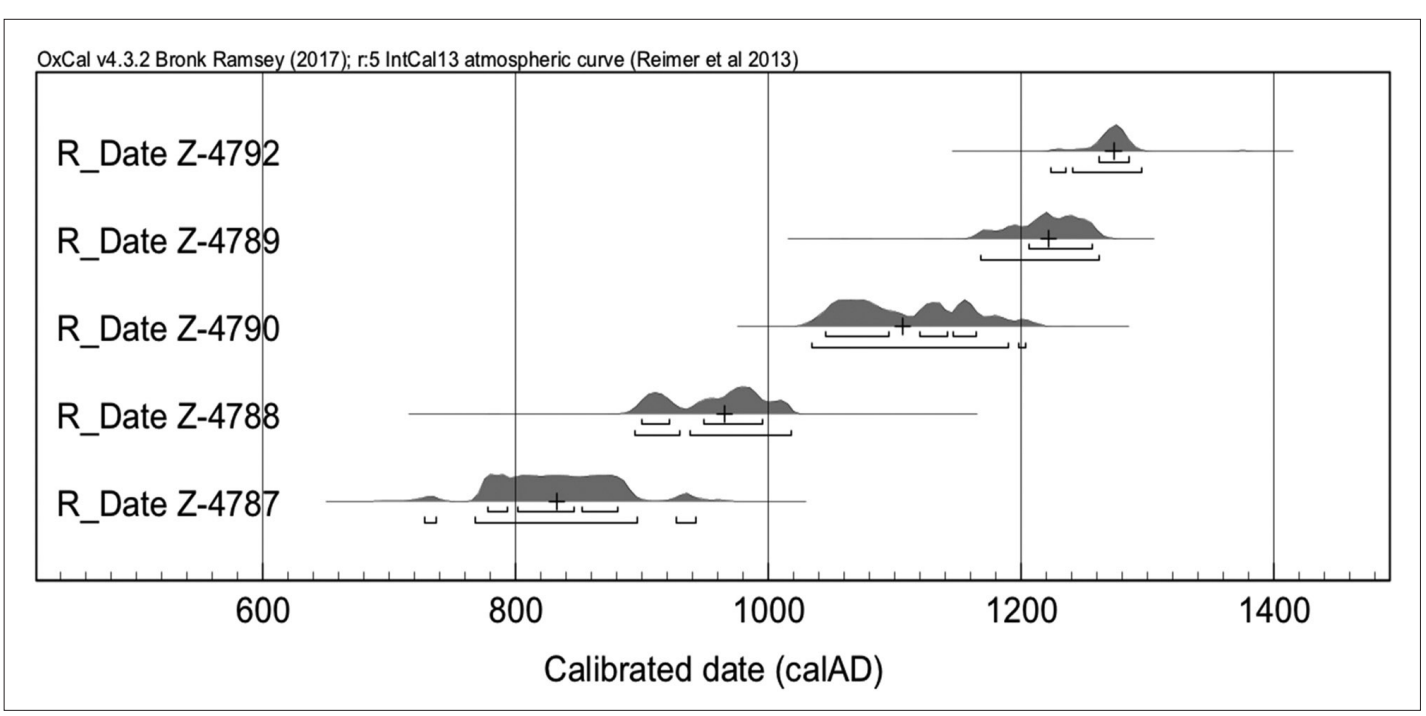

FIGURE 3. Multiplot of recalibrated ranges by $0 x-$ Cal V.4.3.2 (Bronk Ramsey 2017) from Krajcar Bronić et al. (2012) for the bone collagen samples from the graveyard of the St. Stephen in Pustijerna church. "+" mark the median. $Z$ is the Laboratory identification number. Horizontal brackets mark $1 \sigma$ (upper level) and $2 \sigma$ (lower level), i.e., $68.2 \%$ and $95.5 \%$ probability density range(s).

\begin{tabular}{|c|c|c|c|c|c|c|}
\hline Sample name & Z & A & $\begin{array}{c}\text { Conventional } \\
\text { age (BP) }\end{array}$ & $\begin{array}{l}\text { Calibrated } \\
\text { period }\end{array}$ & Median (cal AD) & $\delta^{13} \mathrm{C}(\%)$ \\
\hline $\begin{array}{l}\text { Human bone, } \\
\text { trench 2, grave } 7 \\
\text {-upper graveyard } \\
\text { level }\end{array}$ & 4792 & 386 & $735 \pm 30$ & $\begin{array}{c}\text { Cal AD } 1262- \\
1285 \\
(68.2 \%)\end{array}$ & 1273 & -19.5 \\
\hline $\begin{array}{l}\text { Human bone, } \\
\text { trench 2, grave } \\
13 \text { - upper } \\
\text { graveyard level }\end{array}$ & 4789 & 385 & $825 \pm 25$ & $\begin{array}{c}\text { Cal AD } 1206- \\
1256 \\
(68.2 \%)\end{array}$ & 1222 & -19.8 \\
\hline $\begin{array}{l}\text { Human bone, } \\
\text { original burial, } \\
\text { trench } 2 \text {, grave } \\
8 \text {-synchronous } \\
\text { with construction } \\
\text { of chapel floor }\end{array}$ & 4790 & 394 & $910 \pm 30$ & $\begin{array}{l}\text { Cal AD } 1045- \\
1095(39.6 \%) \\
\text { Cal AD } 1120- \\
1142(15.6 \%) \\
\text { Cal AD } 1146- \\
1164(13.0 \%)\end{array}$ & 1106 & -18.0 \\
\hline $\begin{array}{l}\text { Human bone, } \\
\text { trench 2, grave } \\
22-\text { bottom of } \\
\text { older graveyard } \\
\text { level - with } \\
\text { construction }\end{array}$ & 4788 & 381 & $1080 \pm 30$ & $\begin{array}{c}\text { Cal AD } 900-922 \\
(20.5 \%) \\
\text { Cal AD } 949-995 \\
(47.7 \%)\end{array}$ & 965 & -20.0 \\
\hline $\begin{array}{l}\text { Human bone- } \\
\text { forearm, trench } \\
2 \text {, grave } 33-\text { the } \\
\text { oldest grave }\end{array}$ & 4787 & 393 & $1190 \pm 30$ & $\begin{array}{c}\text { Cal AD } 778-793 \\
(11.7 \%) \\
\text { Cal AD } 801-846 \\
(34.5 \%) \\
\text { Cal AD } 852-880 \\
(21.9 \%)\end{array}$ & 832 & -20.0 \\
\hline
\end{tabular}

Table 2. List of human bone samples excavated from St. Stephen in Pustijerna church during 2011/2012 excavations, their conventional ages, calibrated periods with median and $\delta^{13} \mathrm{C}$ values for the bone collagen. Conventional age is rounded according to the Radiocarbon journal recommendations; the calibrated period is within $68.2 \%(1 \sigma)$ probability of result, numbers in brackets are probabilities for discontinued periods; $1 \sigma$ for $\delta^{13} \mathrm{C}$ is $\pm 0.1 \%$. $Z$ is a laboratory identification number; $\mathrm{A}$ is the number of graphite target. Re-calibrated by OxCal v.4.3.2 (Bronk Ramsey 2017) from Krajcar Bronić et al. (2012) 


\section{Conclusion}

In the Zagreb Radiocarbon Laboratory, radiocarbon dating by the AMS technique was introduced a decade ago enabling dating of milligram size samples, which resulted in an increase in the dating of collagen from archaeological bone remains. AMS also opened a possibility for the dating of apatite from cremated bones. International intercomparison exercises (VIRI and SIRI) among other types of samples contained bone samples for collagen extraction which was analyzed in the Laboratory. The date values from the Laboratory showed very good matching with the consensus values.

Two case studies of the archaeological dating of the bone collagen from the Sokol fortress in Konavle and the graveyard of the St. Stephen in Pustijerna church, Dubrovnik, were conducted. The measured dates proved the existence of the settlement/graveyard in the continuation, for the Sokol fortress, from $6^{\text {th }}$ to $16^{\text {th }}$ century and for the St. Stephen church graveyard from $9^{\text {th }}$ until the $13^{\text {th }}$ century.

\section{Acknowledgement}

We are thankful to Nikolina Topić for checking and approving the part about the archaeological case studies. 


\section{References}

Arnold, J. R. and Libby, W. F. 1949. Age determinations by radiocarbon content: Checks with samples of known age, Science 110 (2869), 678-80.

Ascough, P. L., Cook, G. T., Church, M. J., Dugmore, A. J., McGovern, T. H., Dunbar, E., Einarsson, Á., Friðriksson, A. and Gestsdóttir, H. 2007. Reservoirs and radiocarbon: ${ }^{14} \mathrm{C}$ dating problems in Myvatnsseveit, Nothern Iceland, $R a$ diocarbon 49, 947-961.

Ascough, P. L., Church, M. J., Cook, G. T., Dunbar, E., Gestsdóttir, H., McGovern, T. H., Dugmore, A. J., Friðriksson, A. and Edwards, K. J. 2012. Radiocarbon reservoir effects in human bone collagen from northern Iceland, Journal of Archaeological Science 39, 2261-2271.

Berger, R., Horny, A. G. and Libby, W. F. 1964. Radiocarbon dating of bone and shell from their organic components, Science 144, 999-1001.

Brock, F., Higham, T. and Bronk Ramsey, C. 2010a. Prescreening techniques for identification of samples suitable for radiocarbon dating of poorly preserved bones, Journal of Archaeological Sciences 37, 855-865.

Brock, F., Higham, T., Ditchfield, P. and Bronk Ramsey, C. 2010b. Current pretreatment methods for AMS radiocarbon dating at the Oxford Radiocarbon Acceleration Unit, Radiocarbon 52 (1), 103-12.

Bronk Ramsey, C., Higham, T., Bowles, A. and Hedges, R. 2004. Improvements to the Pretreatment of Bone at Oxford, Radiocarbon 46, 155-163.

Bronk Ramsey, C. 2017. The OxCal program v 4.3.2. The Oxford Radiocarbon Accelerator Unit, University of Oxford, URL: https://c14.arch.ox.ac.uk/oxcal/OxCal.html (Accessed: 21. 2. 2019.).

Brown, T. A., Nelson, D. E., Vogel, J. S. and Southon, J. R. 1988. Improved Collagen Extraction by Modified Longin Method, Radiocarbon 30, 171-177.

Bruhn, F., Duhr, A., Grootes, P., Mintrop, A. and Nadeau, M.-J. 2001. Chemical removal of conservation substances by 'soxhlet'-type extraction, Radiocarbon 43 (2A), 229-37.

DeNiro, M. J. and Epstein, S. 1981. Influence of diet on the distribution of nitrogen isotopes in animals, Geochimica et Cosmochimica Acta 45, 341-351.

Dunbar, E., Cook, G. T., Naysmith, P., Tripney, B. G. and Xu, S. 2016. AMS ${ }^{14} \mathrm{C}$ Dating at the Scottish Universities Environmental Research Centre (SUERC) Radiocarbon Dating Laboratory, Radiocarbon 58, 9-23.

Dury, J. P. R., Eriksson, G., Fjellström, M., Wallerstörm, T. and Liden, K. 2018. Consideration of freshwater and multiple marine reservoir effects: dating of individuals with mixed diets from northern Sweden, Radiocarbon 60, 1561-1685.
Fischer, A., Olsen, J., Richards, M., Heinemeier, J., Sveinbjorndottir, A. E. and Bennike, P. 2007. Coast-inland mobility and diet in the Danish Mesolithic and Neolithic: evidence from stable isotope values of humans and dogs, Journal of Archaeological Science 31, 2125-2150.

Glimcher, M. J. 2006. Bone: nature of the calcium phosphate crystals and cellular, structural, physical chemical mechanisms in their formation, Reviews in Mineralogy and Geochemistry 64, 223-282.

Goh, K. M. and Molloy, B. P. J. 1972. Reliability of radiocarbon dates from buried charcoals, Proceedings of the 8th International Radiocarbon Conference on Radiocarbon dating, The Royal Society of New Zealand, Wellington, 565-581.

Gupta, S. K. and Polach, H. A. 1985. Radiocarbon dating practices at ANU, Handbook, Radiocarbon Laboratory, Research School of Pacific Studies, Australian National University, Canberra.

Haynes, V. 1968. Radiocarbon: Analyses of inorganic carbon of fossil bone and enamel, Science 161, 687-688.

Higham, T., Jacobi, R. M. and Bronk Ramsey, C. 2006. AMS radiocarbon dating of ancient bone using ultrafiltration, Radiocarbon 48 (2), 179-195.

Hoefs, J. 1997. Stabile isotope geochemistry, Springer Verlag, Berlin, Heidelberg.

Horvatinčić, N., Srdoč, D., Obelić, B. and Sliepčević, A. 1983. Radiocarbon dating of fossil bones, development of a new technique for sample processing, Journal of the European Study Group on Physical, Chemical and Mathematical Techniques Applied to Archaeology 8, 377-384.

Horvatinčić, N., Barešić, J., Krajcar Bronić, I. and Obelić, B. 2004. Measurement of Low ${ }^{14} C$ Activities in Liquid Scintillation Counter in the Zagreb Radiocarbon Laboratory, $R a$ diocarbon 46, 105-16.

Hughen, K. A., Baillie, M. G. L., Bard, E., Beck, J. W., Bertrand, C. J. H., Blackwell, P. G., Buck, C. E., Burr, G. S., Cutler, K. B., Damon, P. E., Edwards, R. L., Fairbanks, R. G., Friedrich, M., Guilderson, T. P., Kromer, B., McCormac, G., Manning, S., Bronk Ramsey, C., Reimer, P. J., Reimer, R. W., Remmele, S., Southon, J. R., Stuiver, M., Talamo, S., Taylor, F. W., van der Plicht, J. and Weyhenmeyer, C. E. 2004. Marine04 marine radiocarbon age calibration, 0-26 cal kyr BP, Radiocarbon 46 (3), 1059-1086.

Hüls, M., Grootes, P. M. and Nadeau, M-J. 2007. How Clean is Ultrafiltration Cleaning of Bone Collagen?, Radiocarbon 49 (2), 193-200.

Hüls, C. M., Erlenkeuser, H., Nadeau, M.-J., Grootes, P. M. and Andersen, N. 2010. Experimental Study on the Origin of Cremated Bone Apatite Carbon, Radiocarbon 52 (2-3), 587-599. 
Johansen, O. S., Gulliksen, S. and Nydal, R. 1986. $\delta^{13} \mathrm{C}$ and diet: Analysis of Norwegian human skeletons, Radiocarbon 28 (2A), 754-761.

Krajcar Bronić, I., Horvatinčić, N., Barešić, J. and Obelić, B. 2009. Measurement of ${ }^{14} \mathrm{C}$ activity by liquid scintillation counting, Applied Radiation and Isotopes 67, 800-804.

Krajcar Bronić, I., Horvatinčić, N., Sironić, A., Obelić, B., Barešić, J. and Felja, I. 2010. A new graphite preparation line for $\mathrm{AMS}{ }^{14} \mathrm{C}$ dating in the Zagreb Radiocarbon Laboratory, Nuclear Instruments and Methods in Physics Research B 268, 943-946.

Krajcar Bronić, I., Topić, N., Radić, I., Peković, Ž. and Sironić, A. 2012. Radiocarbon dating of St. Stephen's in Pustijerna church in Dubrovnik, Croatia, In: R. Radvan, S. Akzuy and M. Simileanu (eds), The Unknown Face of the Artwork, Istanbul Kultur University, Istanbul, 27-34.

Krajcar Bronić, I., Horvatinčić, N. and Barešić, J. 2015a. Results of the Laboratory for low-level radioactivity (RBI) in international intercomparisons TRIC2012 and SIRI- ${ }^{14} \mathrm{C}$ (In Croatian with English abstract: Rezultati Laboratorija za mjerenje niskih radioaktivnosti (IRB) u međunarodnim interkomparacijama TRIC2012 i SIRII- $\left.{ }^{14} \mathrm{C}\right)$, In: B. Petrinec, T. Bituh, M. Milić and N. Kopjar (eds), Proceedings on the Tenth symposium of the Croatian Radiation Protection Association, Zagreb, Croatia CRPA, 395-390.

Krajcar Bronić, I., Topić, N., Drašković Vlašić, N., Peković, Ž., Barešić, J., Sironić, A. and Borković, D. 2015b. Radiocarbon dating of burial and seed samples from the Sokol fortress in Konavle near Dubrovnik, Croatia, ISRP13 - The $13^{\text {th }}$ International Symposium on Radiation Physics, 7 - 9 September 2015, Beijing, China.

Lamb, A. L., Melikian, M., Ives, R. and Evans, J. 2012. Multiisotope analysis of the population of the medieval village of Auldhame, East Lothian, Scotland, Journal of Analytical Atomic Spectrometry 27, 765-777.

Lanting, J. N., Aerts-Bijma, A. T. and van der Plicht, J. 2001. Dating of cremated bones, Radiocarbon 43 (2A), 249-254.

Libby, W. F. 1955. Radiocarbon Dating, University of Chicago Press, Chicago.

Libby, W. F., Anderson, E. C. and Arnold, J. R. 1949. Age determination by radio-carbon content: world-wide assay of natural radiocarbon, Science 109, 227-228.

Lightfoot, E., Šlaus, M., Rajić Šikanjić, P. and O'Connel, T. C. 2014. Metals and millets: Bronze and Iron Age diet in inland and coastal Croatia seen through stable isotope analysis, Archaeological and Anthropological Sciences 7, 375-376.

Longin, R. 1971. New method of collagen extraction for radiocarbon dating, Nature 230, 241-242.

Major, I., Dani, J., Kiss, V., Melis, E., Patay, R., Szabó, G., Hubay, K., Túri, M., Futó, I., Huszánk, R., Jull, A. J. T. and Molnár, M. 2019. Adoption and evaluation of a sample pretreatment protocol for radiocarbon dating of cremated bones at HEKAL, Radiocarbon 61 (1), 159-171.

Marom, A., McCullagh, J. S. O., Higham, T. F. G. and Hedges, R. E. M. 2013. Hydroxyproline Dating: Experiments on the ${ }^{14} \mathrm{C}$ Analysis of Contaminated and Low-Collagen Bones, Radiocarbon 55, 698-708.

Mook, W. G. 2000. Environmental Isotopes in the Hydrological Cycle, Principles and Applications, Technical Documents in Hydrology, Paris, UNESCO/IAEA, 39 (1) 280.

Mook, W. G. and van der Plicht, J. 1999. Reporting ${ }^{14} \mathrm{C}$ activities and concentrations, Radiocarbon 41, 227-239.

Naysmith, P., Scott, E. M., Cook, G. T., Heinemeier, J., van der Plicht, J., Van Strydonck, M., Bronk Ramsey, C., Grootes, P. M. and Freeman, S. P. H. T. 2007. A cremated bone intercomparison study, Radiocarbon 49 (2), 403-408.

Olsen, J., Heinemeier, J., Bennike, P., Krause, C., Hornstrup, K. M. and Thrane, H. 2008. Characterisation of blind testing of radiocarbon dating of cremated bone, Journal of Archaeological Sciences 35, 791-800.

Olsen, J., Heinemeier, J., Hornstrup, K. M., Bennike, P. and Thrane, H. 2013. 'Old wood' effect in radiocarbon dating of prehistoric cremated bones?, Journal of Archaeological Science 40 (1), 30-34.

Peković, Ž. 1998. Dubrovnik - Beginning and development of Middle Ages town. Dubrovnik - nastanak i razvoj grada, Katalozi i monografije 5, Split, Muzej hrvatskih arheoloških spomenika, 146.

Peković, Ž. 2010. Conservation study report for the Church St. Stephen in Pustijerna in Dubrovnik. Crkva Sv. Stjepana - Konzervatorski elaborat, Internal publication, Omega engineering d.o.o., Dubrovnik.

Reimer, P. J., Bard, E., Bayliss, A., Beck, J. W., Blackwell, P. G., Bronk Ramsey, C., Buck, C. E., Cheng, H., Edwards, R. L., Friedrich, M., Grootes, P. M., Guilderson, T. P., Haflidason, H., Hajdas, I., Hatté, C., Heaton, T. J., Hoffmann, D. L., Hogg, A. G., Hughen, K. A., Kaiser, K. F., Kromer, B., Manning, S. W., Niu, M., Reimer, R. W., Richards, D. A., Scott, E. M., Southon, J. R., Staff, R. A., Turney, C. S. M. and van der 
Plicht, J. 2013. IntCal13 and Marine13 Radiocarbon Age Calibration Curves 0-50,000 Years cal BP, Radiocarbon 55, 1869-1887.

Regan, K. and Nadilo, N. 2006. Crkveno graditeljstvo: Ranoromaničke sakralne građevine dubrovačkog područja (II.), Građevinar 58, 231-242.

Salazar-Garcia, D. C., Aura, J. E., Olaria, C. R., Talamo, S., Morales, J. V. and Richards, M. P. 2014. Isotope evidence for the use of marine resources in the Eastern Iberian Mesoltitic, Journal of Archaeological Science 42, 231-240.

Sayle, K. L., Cook, G. T., Ascough, P., Gestsdottir, H., Hamilton, W. D. and McGovern, T. H. 2014. Utilization of $\delta^{13} C$, $\delta^{15} \mathrm{~N}$ and $\delta^{34} S$ analyses to understand ${ }^{14} \mathrm{C}$ dating anomalies within a late Viking age community in northeast Iceland, Radiocarbon 56, 811-821.

Schoeninger, M. J., DeNiro, M. J. and Tauber, H. 1983. ${ }^{15} \mathrm{~N} /{ }^{14} \mathrm{~N}$ Ratios of bone collagen reflect marine and terrestrial components of Prehistoric diets, Science 220, 13811383.

Scott, E. M., Cook, G. T., Naysmith, P., Bryant, C. and O'Donnell, D. 2007. A report on Phase 1 of the $5^{\text {th }}$ International Radiocarbon Intercomparison (VIRI), Radiocarbon 49 (2), 409-426.

Scott, E. M., Cook, G. T. and Naysmith, P. 2010a. A report on Phase 2 of the Fifth International Radiocarbon Intercomparison (VIRI), Radiocarbon 52 (2-3), 846-858.

Scott, E. M., Cook, G. T. and Naysmith, P. 2010b. The Fifth International Radiocarbon Intercomparison (VIRI): An assessment of laboratory performance in stage 3 , Radiocarbon 52 (2-3), 858-865.

Scott, E. M., Cook, G. T. and Naysmith, P. 2017. Should archaeologists care about ${ }^{14} \mathrm{C}$ intercomparisons? Why? A summary report on SIRI, Radiocarbon 59 (5), 1589-1596.

Sironić, A., Krajcar Bronić, I., Horvatinčić, N., Barešić, J., Obelić, B. and Felja, I. 2013. Status report on the Zagreb Radiocarbon Laboratory- AMS and LSC results of VIRI intercomparison samples, Nuclear Instruments and Methods in Physics Research B 294, 185-188.

Srdoč, D., Breyer, B. and Sliepčević, A. 1971. Ruđer Bošković Institute Radiocarbon Measurements I, Radiocarbon 13 (1), 135-140.
Srdoč, D., Sliepčević, A., Planinić, J., Obelić, B. and Breyer, B. 1973. Ruđer Bošković Institute Radiocarbon Measurements II, Radiocarbon 15, 435-441.

Topić, N., Radić, I. and Peković, Ž. 2012. Archaeological report. Arheološko izvješće, Internal publication, Omega engineering d.o.o., Dubrovnik.

Topić, N., Bedić, Ž, Vyroubal, V., Šlaus, M., Barešić, J., Sironić, A., Ilkić, M., Moore, A. M. T. and Drašković Vlašić, $\mathrm{N}$. Inventory of finds and multiphase cemetery along the Sokol fortress in Konavle. Inventar nalaza i višefazno groblje uz utvrdu Sokol u Konavlima), Archaeologia Adriatica, In press.

Tütken, T. and Vennemann, T. W. 2011. Fossil bones and teeth: Preservation or alteration of biogenic composition, Palaeogeography, Palaeoclimatology, Palaeoecology 310, 1-8.

van Klinken, G. J. 1999. Bone collagen quality indicators for paleodietary and radiocarbon measurements, Journal of Archaeological Sciences 26, 687-395.

van Strydonck, M., Boudin, M., Hoefkens, M. and De Mulder, G. 2005. ${ }^{14} \mathrm{C}$-dating of cremated bones, why does it work?, LUNULA (BRUSSEL), 13, 3-10

van Strydonck, M., Boudin, M. and De Mulder, G. 2009. ${ }^{14} \mathrm{C}$ Dating of Cremated Bones: The Issue of Sample Contamination, Radiocarbon 51 (2), 553-568.

Waller, S. and Mewis, J. 1979. Occurrence of C3 and C4 photosynthetic pathways in north American grasses, Journal of Range Management 32 (1), 12-28.

Wopenka, B. and Pasteris, J. D. 2005. A mineralogical perspective on the apatite in bone, Materials Science and Engineering C 25, 131-143.

Yuan, S., Wu, X., Gao, S., Wang, J., Cai, L., Liu, K., Li, K. and $\mathrm{Ma}, \mathrm{H}$. 2000. Comparison of different bone pretreatment methods for AMS $14 \mathrm{C}$ dating, Nuclear Instruments and Methods in Physics Research Section B 172 (1-4), 424-427.

Zazzo, A. and Saliège, J.-F. 2011. Radiocarbon dating of biological apatites: A review, Palaeogeography, Palaeoclimatology, Palaeoecology 310, 52-61. 